\begin{tabular}{|l|l|l|}
\hline \multicolumn{2}{|c|}{ PublisherInfo } \\
\hline \hline PublisherName & $:$ & BioMed Central \\
\hline \hline PublisherLocation & $:$ & London \\
\hline \hline PublisherImprintName & $:$ & BioMed Central \\
\hline \hline
\end{tabular}

\title{
Max Planck announces cuts
}

\begin{tabular}{|l|l|l||}
\hline \multicolumn{2}{|c|}{ ArticleInfo } \\
\hline \hline ArticleID & $:$ & 4787 \\
\hline \hline ArticleDOI & $:$ & $10.1186 /$ gb-spotlight-20030611-01 \\
\hline \hline ArticleCitationID & $:$ & spotlight-20030611-01 \\
\hline \hline ArticleSequenceNumber & $:$ & 139 \\
\hline \hline ArticleCategory & $:$ & Research news \\
\hline ArticleFirstPage & $:$ & 1 \\
\hline \hline ArticleLastPage & $:$ & 3 \\
\hline \hline & & RegistrationDate : 2003-6-11 \\
\hline ArticleHistory & $:$ & OnlineDate \\
\hline \hline ArticleCopyright & $:$ & BioMed Central Ltd2003-6-11 \\
\hline \hline ArticleGrants & $:$ & \\
\hline \hline ArticleContext & $:$ & 130594411 \\
\hline \hline
\end{tabular}


On Thursday, June 5, the Max Planck Society (MPG) announced the closure of 12 research departments and one institute in order to cope with its decreased annual budget. The cuts will save the MPG $€ 50$ million (\$58.8 million) annually.

The announcement vindicates concerns expressed in December 2002, when the German government decided to freeze the budgets of the public research organizations at 2002 levels. Since then, chancellor Gerhard Schröder has promised a 3\% budget increase per year beginning in 2004. But in order to fund its 80 research institutes and 12,000 employees, the MPG needs an annual budget increase of at least $4 \%$.

"The freeze really hurts," Christina Beck of the MPG told The Scientist, "because it actually means less money, not least because of increased personnel costs due to tariff rises." She added that recruiting a new research director now costs roughly 1.3 times more than in the past. This means funding for only three new directors when four directors retire.

The budget freeze came at a time when the MPG was already struggling financially. In the 1990s, it received extra funding to pay for its part in "Aufbau Ost," the rebuilding of eastern Germany. The MPG opened 20 new research institutes in the new Länder; the last building works were only finished this year, and nine of 57 research director positions at the new institutes in the east still need to be filled. But the extra funding for Aufbau Ost dried up in 2000, and the MPG drew criticism from research minister Edelgard Bulmahn for having taken so much time and having wasted funds in the early 1990s.

"It is easy to say that we were too slow," countered Beck. "I would say we have been careful and thorough. The MPG is well advised to take its time in choosing directors carefully, if it wants to keep its international reputation for conducting excellent research."

In order to continue to be able to afford the best scientists, the MPG decided to adopt a strategy of cuts that wouldn't compromise its reputation. It identified department directors due for retirement by 2007 and then assessed the potential of the research in those departments. "We wondered where we can expect scientific breakthroughs in the next few years," explained Beck, "either because many scientists are active in a certain field or because there have been recent methodological breakthroughs in a certain area and scientists are now ready to reap the rewards." In addition, the research was assessed on the basis of its relevance to human needs today (for example, biomedical research would be valued higher than research into establishing a space station on Mars).

If a department director in a nonpriority research area retires within the next few years, the department will be closed and the remaining scientists offered positions in other departments/institutes.

As a result of this strategy, a whole department will be closed at the Max Planck Institute (MPI) for Medical Research in Heidelberg, at the MPI for Neurological Research in Cologne, at theMPI for Experimental Medicine in Göttingen, and at eight other institutes that conduct research outside the life sciences. 
The Limnological River Station in Schlitz, an outstation belonging to the MPI for Limnology in Plön, will also be shut down.

Moreover, almost one third of the MPG's independent junior research groups, which usually run for 5 years, will be discontinued once the current period is over.

The MPG also looked at which institutes might logically be merged with others. It decided to close the MPI of Experimental Endocrinology in Hannover, which comprises only one research department, led by Gregor Eichele. That department will be moved to the MPI for Biophysical Chemistry in Göttingen.

Eichele was overseas at the time of posting of this article, but Karola Neubert, spokeswoman for the MPI of Experimental Endocrinology, said, "Gregor Eichele views this as an opportunity... Göttingen has an excellent research environment, and Eichele's department will fit in well with the MPI for Biophysical Chemistry."

\section{References}

1. Max Planck Society, [http://www.mpg.de/english/]

2. M. Habeck, "German funding freeze," The Scientist, December 4, 2002., [http://www.thescientist.com/news/20021204/02/]

3. Federal Ministry for Education and Research, [http://www.bmbf.de/en/index.php3]

4. Max Planck Institute for Medical Research, [http://www.mpimf-heidelberg.mpg.de/]

5. Max Planck Institute for Neurological Research, [http://www.mpin-koeln.mpg.de/english/index.htm]

6. Max Planck Institute for Experimental Medicine, [http://www.mpiem.gwdg.de/index_en.html]

7. Limnological River Station Schlitz, [http://www.mpil-schlitz.mpg.de/englisch/index.html]

8. Max Planck Institute for Limnology, [http://www.mpil-ploen.mpg.de/english/index.htm]

9. Max Planck Institute of Experimental Endocrinology, [http://www.endo.mpg.de/english/index.htm]

10. Max Planck Institute for Biophysical Chemistry, [http://www.mpibpc.gwdg.de/index_en.html] 